\title{
Group Dynamics and Student Self-Efficacy in Online Science Learning during the COVID-19 Pandemic
}

\author{
Linda Kusumawati ${ }^{*}$, Ari Widodo², Diana Rochintaniawati ${ }^{3}$ \\ ${ }^{1}$ Master of Science Education Study Program, Graduate School of the Indonesian University of Education, Bandung, Indonesia \\ 2Department of Biology Education, Indonesian University of Education, Bandung, Indonesia \\ 3International Program on Science Education, Universitas Pendidikan Indonesia, Bandung, Indonesia
}

DOI: $10.29303 /$ ippipa.v7i4.760

\section{Article Info}

Received: May 24th, 2021

Revised: September $6^{\text {th }}, 2021$

Accepted: October 3rd, 2021

\begin{abstract}
The complex problems of online learning in synchronous and asynchronous because of a reduction in the social life of students. It is necessary to do collaborative learning to observe the dynamics of the interactions in groups during learning. The purpose of this study was to observe group dynamics and student self-efficacy during online learning. The study uses descriptive qualitative methods with data triangulation through observations, interviews and surveys. Junior high school research subjects used the discussion method with asynchronous learning on WhatsApp group (WAG). The high school subjects used the discussion method with synchronous learning on the WAG. Aspects that are observed in group dynamics are the division of roles in groups, leadership, contributions when presenting ideas or ideas, contribution to task work, and interdependence in groups. Self-efficacy was observed using indicators of mastery experience $78 \%$ junior high school and $73.3 \%$ high school, vicarious experience $76.5 \%$ junior high school and $78.1 \%$ high school, verbal persuasion $71.4 \%$, physiological and affective states $75.6 \%$. The average percentage of students' self-efficacy was in the medium category, namely $74.2 \%$ for junior high school and $75.6 \%$ for senior high school.
\end{abstract}

Keywords: Group dynamics; Self-efficacy; Asynchronous; Synchronous

Citation: Kusumawati, L., Widodo, A., \& Rochintaniawati, D. (2021). Group Dynamics and Student Self-Efficacy in Online Science Learning during the COVID-19 Pandemic. Jurnal Penelitian Pendidikan IPA, 7(4), 568-575. doi:https://doi.org/10.29303/jppipa.v7i4.760

\section{Introduction}

All levels of education experience the complex problems of online learning during the pandemic. Material content that students, passive and unidirectional learning do not well understand from teacher to student, limited ability to use technology, and limited teacher control over students are problems that are often encountered in online learning (Asmuni, 2020).

Adaptation towards a better direction in online learning must be made, because it has been running for more than a year. Online learning must also pay attention to achievement competencies in each learning, both cognitive, psychomotor, or affective aspects. Basically, the learning process is complex because it involves pedagogical and psychological students, so online learning activities are not just transfer of knowledge by sending materials and assignments via the internet or social media as is widely applied to online learning in Indonesia (Asmuni, 2020; Syarifudin, 2020). Online learning must still be accompanied by an interactive and collaborative learning process so that it can provide meaningful experiences and efforts to grow character in students.

The transformation of learning from classical outside the network (offline) to online brings up several impacts on students, namely the inability of students to find the meaning of learning and the loss of social life. This happens because there is no social interaction between students, and if it continues, it will potentially create social and emotional distance among students

\footnotetext{
*Email: Lindakusumawati26@gmail.com
} 
(Asriadi, 2021). So far, social presence in learning has been proven to bring significant results to learning outcomes and train and develop group skills (collaboration) as an implementation in 21st-century skill learning (Tantri, 2018). Thus, online learning can be optimized by using group learning methods to foster social presence in students.

Group learning methods are often used as a form of collaborative learning but are limited to giving assignments so that learning is more efficient and optimal. However, dynamics in groups such as events and interactions between students are rarely observed, even though teachers can use them to determine the learning patterns of each student. Group dynamics activities can provide opportunities for students to build relationships, exchange ideas, solve problems, and learn to tolerate differences of opinion between students (Asnur et al., 2019; Syarifudin, 2020).

Group learning activities can be done online, both synchronous learning and asynchronous learning. Synchronous learning is a learning process that takes place at the same time as face-to-face, while asynchronous learning is learning-centered on an independent learning approach with relevant online learning resources (Asriadi, 2021). Synchronous distance learning is facilitated by direct instructions in real-time, while asynchronous can be done anywhere and anytime according to the time they choose.

One of the characteristics in students that are able to influence the process and student learning outcomes is self-efficacy. Self-efficacy is a form of confidence, trust, and motivation in students to be able to do the tasks given by the teacher (Avsec \& Szewczyk-Zakrzewska, 2018; Y. shan Chang et al., 2019; Huang et al., 2020). Cell efficacy can also influence individuals in estimating their cognitive abilities and capacities to act in stressful situations (Oktariani, 2018).

Based on the results of previous studies, students who have low self-efficacy tend to avoid many and difficult tasks compared to students who have high self-efficacy. This is because students with high selfefficacy are more trying to master the task optimally (Oktariani, 2018; Sunaryo, 2017). Self-efficacy also affects student learning outcomes, where students who have low self-efficacy tend to get low learning outcomes compared to students who have high selfefficacy (Sunaryo, 2017). Self-efficacy also affects the mindset of each student, where students who have high self-efficacy will tend to be open-minded, flexible in solving problems, compared to students who have low self-efficacy who will be more rigid and closed-minded (Puente-Díaz \& Cavazos-Arroyo, 2017; Royston \& Reiter-Palmon, 2019).

One of the factors that influence self-efficacy is the experience that students have had. These experiences can be in the form of learning experiences given by teachers to students or experiences students get in everyday life (Chang et al., 2016; Zhang et al., 2020). One of the experiences that can be given to students is a learning experience using various learning methods.

The explanation shows that self-efficacy is one of the potentials that must be developed in students, especially students who enter the age of teenagers who range from 13 to 16 years. At this time,, students are looking for identity so that their thinking becomes abstract, logical, and idealistic. Self-efficacy here provides an important role to be grown so that it can have a strong influence on students to be diligent, exert their abilities to the maximum in doing tasks and affect their learning achievement (Heirida, 2017).

This study aimed to determine the level of student self-efficacy in learning through group dynamics activities. In group learning activities or doing assignments in groups, there will be an interaction between students in groups and between teachers and students regarding the tasks given by the teacher. This will be analyzed to determine the level of activeness and dominance of students' roles in group discussions. Furthermore, self-efficacy questionnaires will be filled out to see the relationship between the level of student activity in group discussions and the level of self-efficacy in students.

\section{Method}

The research method used is the descriptive qualitative method. Researchers are directly involved in research activities to observe student interactions in groups, conduct interviews with students and teachers, and provide surveys on research subjects. The subjects of the study were class VII students at SMP Negeri in Banyuwangi, East Java, with a total of 23 students, and class XI students at a State Senior High School in Nusa Lembongan Bali, with a total of 27 students. Subject selection was carried out by purposive sampling, namely sampling based on certain considerations. The considerations used are class VII and class XI, the middle class where students already have learning experiences at each level. In addition, in-class VII and class XI both study the same material, namely the excretory system and, of course, with different content coverage.

The first step in this study was to form 4 WhatsApp groups at the junior and senior high school levels so that there were 8 WhatsApp groups to be observed. In each group, some teachers facilitate and guide discussion activities, and there are researchers as observers of group discussion activities. 
In the second step, the researcher plays a passive role in the group, only observing and recording every interaction between the teacher and students or between members in the group according to the group dynamics observation sheet guidelines and additional notes about the interaction scheme if needed. The researcher's observation sheet compiled and developed contains aspects used for observing group dynamics and observation sheets about aspects of the teacher's role in group dynamics. According to the group dynamics observation sheet, aspects that can be observed include the division of roles in the group, leadership, contributions when expressing ideas or ideas, contributions when working on tasks, and interdependence in groups. The aspects used to observe the teacher's role in group dynamics include support from the teacher, awards or rewards from the teacher, feedback or feedback on learning outcomes, and guidance given to students to focus on learning objectives.

The third step is to distribute self-efficacy questionnaires or questionnaires online to each group and ask students to fill in all available questions in the form of a Likert scale. Not all research samples filled out the self-efficacy questionnaire. Only 38 students filled it out and will be analyzed in this study. There are 25 questions in the self-efficacy questionnaire with positive and negative question models.

The fourth step conducted interviews to confirm and explore further the reasons for the interactions carried out by some students or teachers based on the researcher's observations on certain events. Interviews were also conducted by looking at the level of selfefficacy that students had filled in to compare the high and low self-efficacy in the questionnaire and the level of student activity in group dynamics activities.

Data collection techniques are carried out by data triangulation or data combination. Data triangulation is a data collection technique that combining various data collection techniques and existing data sources. The triangulation used is the triangulation method, where in this case, the researcher conducts observations, interviews, and surveys.

\section{Results and Discussion}

Based on the results of observations that have been made at the two schools, namely junior high school and high school, it can be seen that there is a difference in group dynamics in online learning. For junior high school students, group discussions are carried out asynchronously via WhatsApp Group (WAG) with a time span of 4 days for discussion and task execution. While at the high school level, group discussions are carried out synchronously via WAG with a span of 90 minutes according to the school's lesson schedule. The group is divided by the teacher heterogeneously with the aim that there is no discrimination in the selection of group members (Juniar et al., 2018). The difference between asynchronous and synchronous learning impacts the way of interaction in each group and the difference in the teacher's role in guiding the discussion process. Data on the observational aspects of group dynamics were analyzed and calculated based on the number of frequency groups that applied aspects of group dynamics.

Table 1. Frequency of occurrence of Group Dynamics Aspects of Division of Roles in Groups.

\begin{tabular}{llll}
\hline Group Dynamic & Sub Aspect & $\begin{array}{l}\text { Middle School } \\
\text { Group Frequency } \\
\text { (Asynchronous) }\end{array}$ & $\begin{array}{l}\text { Group Frequency } \\
\text { senior High School } \\
\text { (Synchronous) }\end{array}$ \\
\hline Aspect & & 3 & 0 \\
\hline Division of Roles in Groups & The role is determined by one of the members & 4 \\
& Role on the initiative of each member & 1 & 4 \\
\hline
\end{tabular}

Aspects of the division of roles in groups were observed to know the dynamics of the division of roles that occurred between group members. The division of roles in the group serves to eliminate the domination factor of one group member and increase the participation of each member so that all members can express ideas and get a balanced role for task work (Juniar et al., 2018). The observations show that the dominant role division performed by junior high school students is the determination of the role by one of the group members who is the most prevalent in controlling the members of the group. Meanwhile, for high school students, the division of roles is carried out on the initiative of each student in the group independently. Teachers in the junior high and high school groups gave instructions to students to focus on the tasks assigned by the teacher, while junior high school teachers condition students when they start to focus less on the task at hand. This is because asynchronous learning in junior high school students takes a long time (Narayana, 2016), so it takes several instructions to focus and ask the progress of the tasks that students are doing. 
Table 2. Frequency of occurrence of Leadership Aspect Group Dynamics

\begin{tabular}{llll}
\hline Group Dynamic & & $\begin{array}{l}\text { Middle School Group } \\
\text { Frequency } \\
\text { (Asyncron) }\end{array}$ & $\begin{array}{l}\text { Group Frequency } \\
\text { senior High School } \\
\text { (Syncron) }\end{array}$ \\
\hline Leadership & Sub Aspect & 4 & 4 \\
& opening discussion & 2 & 0 \\
\cline { 2 - 4 } & Directing the discussion & 3 & 1 \\
& idea host & 2 & 1 \\
\hline
\end{tabular}

Aspects of leadership were observed in groups to determine student attitudes in interacting and activating discussion activities. Leadership determines the final outcome of the discussion because it is related to student leadership and the participation of the members they lead (Juniar et al., 2018). In the junior and senior high school groups, each group has one member who opens discussion activities. For junior high school students, there are more group members who can direct the topic of discussion, mediate and accommodate ideas, and emphasize the purpose of the task. This is because learning that occurs asynchronously makes students more independent, and each group tries to organize the discussion. Students will be more independent in asynchronous learning than synchronous because asynchronous learning is designed for independent learning (Fahmi, 2020). While in the high school group, learning takes place synchronously so that students are less independent, and the teacher's dominance in providing arrangements for the group is more frequent than in asynchronous learning. Synchronous learning occurs in real-time and makes students less time-consuming to discuss and requires smooth internet access to avoid getting truncated information (Narayana, 2016).

Table 3. Frequency of occurrence of Contribution Aspect Group Dynamics when expressing ideas

\begin{tabular}{llll}
\hline Group Dynamic & Sub Aspect & $\begin{array}{l}\text { Middle School Group } \\
\text { Frequency } \\
\text { (Asyncron) }\end{array}$ & $\begin{array}{l}\text { Group Frequency } \\
\text { senior High School } \\
\text { (Syncron) }\end{array}$ \\
\hline Contribute when & Submit an idea & 4 & 4 \\
presenting ideas & Submitting a solution & 2 & 0 \\
& Positive negotiation & 0 & 0 \\
& Negative negotiation & 1 & 1 \\
& Giving explanation on group members & 1 & 1 \\
& Always apply the material in the discussion & 0 & 2 \\
\hline
\end{tabular}

Aspects of student contributions in expressing ideas for junior high and high school students have the same level of activeness and dominance, but group discussions for junior high school students have activities to argue with each other and provide solutions. This is due to differences in the types of tasks and the learning process carried out. For junior high school students, the task is in the form of making a creative mind mapping about the excretory system, while for high school students, it is only a summary of the main discussion of the excretory system. The teacher shows his role by giving rewards in the form of motivational words so that students are more enthusiastic in discussing. The teacher shows support for every student who is not active to express ideas. Giving awards will increase intrinsic motivation in students, so they can actively participate in learning and doing assignments to the maximum so that their goals can be achieved.

Table 4. The frequency of occurrence of Contribution Aspect Group Dynamics when Working on Tasks

\begin{tabular}{llll}
\hline Group Dynamic & Sub Aspect & $\begin{array}{l}\text { Middle School Group } \\
\text { Frequency } \\
\text { (Asyncron) }\end{array}$ & $\begin{array}{l}\text { Group Frequency } \\
\text { senior High School } \\
\text { (Syncron) }\end{array}$ \\
\hline $\begin{array}{lll}\text { Contribute while doing } \\
\text { the task }\end{array}$ & $\begin{array}{l}\text { Guess the needs of the group } \\
\text { Initiative to do the task }\end{array}$ & 4 & 1 \\
& Dominate doing the task & 3 & 4 \\
\hline
\end{tabular}

Aspects of contribution in the work of the task were more observed in the group of junior high school students compared to high school. In junior high school students, they can guess the material needs and the division of tasks for each member, even though a few members only dominate the task. This is because in 
asynchronous learning, many students are not active at the same time, so other group members try to complete the lack of assignments. In asynchronous learning, it is uncertain when students are active in opening groups because each student has a different frequency of discussion time (Dong et al., 2020). The role played by the teacher when students start working on assignments is to provide feedback on the progress that each member in the group has made. The teacher no longer plays the role of giving lessons and detailed steps that students must do, but the teacher functions as a partner, facilitator and not as a formal instructor (Corbett \& Spinello, 2020).

Table 5. Groups of Interdependence Aspects in Groups

\begin{tabular}{llll}
\hline Group Dynamic & Sub Aspect & $\begin{array}{l}\text { Middle School Group } \\
\text { Frequency (Asyncron) }\end{array}$ & $\begin{array}{l}\text { Group Frequency } \\
\text { senior High School (Syncron) }\end{array}$ \\
\hline Aspect & 3 & 4 \\
$\begin{array}{l}\text { Interdependence in } \\
\text { groups }\end{array}$ & $\begin{array}{l}\text { There are members who influence other } \\
\text { members' ideas } \\
\text { There are group members who depend on } \\
\text { other members }\end{array}$ & 3 & 4 \\
\hline
\end{tabular}

Aspects of interdependence in a group is the interaction of mutual influence between group members and the dependence of group members on one of its members. This aspect is seen in all groups at the high school level, while at the junior high school level, only a few groups show interdependence interactions. This is because asynchronous learning causes unequal discussion time interactions. Group interdependence on online learning will make learning effective and positive if each student has a responsibility and all members try to participate actively, and the teacher gives instructions to students to work together in group learning.

Table 6. Percentage of students' self-efficacy indicators

\begin{tabular}{llll}
\hline No & $\begin{array}{l}\text { Indicator } \\
\text { self-efficacy }\end{array}$ & $\begin{array}{l}\text { Percentage Self-efficacy } \\
\text { middle school students (\%) }\end{array}$ & $\begin{array}{l}\text { Percentage Self-efficacy of high } \\
\text { school students }(\%)\end{array}$ \\
\hline 1 & Mastery Experience & 78.1 & 73.7 \\
2 & Vicarious Experience & 76.5 & 78.1 \\
3 & Verbal Persuasion & 71.4 & 77.9 \\
4 & Physiological and Affective States & 70.9 & 72.6 \\
5 & Average & 74.2 & 75.6 \\
& criteria & middle & middle \\
\hline
\end{tabular}

Based on table 6, it can be seen that the selfefficacy indicators used based on Bandura (1997) include mastery experience, vicarious experience, verbal persuasion, physiological and affective states. The highest percentage at the junior high school level is mastery experiences, which is $78.1 \%$, while at the high school level, the highest is vicarious experiences, which is $78.1 \%$. The lowest percentage at junior high school level is $70.9 \%$ and high school level $72.6 \%$, namely physiological and affective states.

The first self-efficacy indicator is mastery experience, which is the highest achieved by junior high school students. Mastery experience is a personal experience experienced by student himself. The experiences that students have gone through produce beliefs that will impact the work performance given by students to work on group assignments (Nurfauziah et al., 2018). Students' self-efficacy in this mystery experience will soar if previously students had a similar discussion experience and it was successfully carried out by involving all their abilities, but if the experience of working in the previous group did not go well, the student's self-efficacy would decrease (Wangwongwiroj \& Yasri, 2021).

The familiarity that is built from communication and experience with other people is also able to increase students' self-efficacy (Martin et al., 2019). Students can meet new people and exchange experiences to inspire and develop themselves (S. H. Chang et al., 2016; Samsudin et al., 2020).

"I often use different methods and learning models and require students to interact with other students to get new experiences and not cause monotony when studying" (Melvia, a junior high school teacher).

The results of interviews with junior high school teachers show that teachers are used to providing different learning experiences to students, one of which is various methods of discussion, group learning experience becomes commonplace and results in a higher student mastery experience. Knowledge can also be in the form of tasks given by the teacher to students. If students often get similar assignments, it will make students more fluent in doing these assignments. Every experience or student mastery of particular learning 
does not grow naturally but through exposure and giving experiences that repeatedly occur in various training activities that were previously obtained (Avsec \& Szewczyk-Zakrzewska, 2018; Vally et al., 2019).

The highest self-efficacy indicator in high school students is vacarious experience. Vacaroius experience is imitating others. A student will be more confident in his abilities if the student has a role model that will be used as a role model to be followed (Nurfauziah et al., 2018). Modeling can be demonstrated in learning through cognitive and simulation modeling, which students can imitate to increase their self-efficacy (Webb \& LoFaro, 2020). Giving an initial view of a task or product to be made helps students focus and be fluent in working on assignments. This is because the initial modeling by giving clear instructions will make students think more critically and creatively in doing group assignments given by the teacher, compared to teachers who do not provide instructions which cause ambiguity of information (Wangwongwiroj \& Yasri, 2021).

"I always give examples of assignments in the form of physical forms or pictures that I will make assignments to students, because so that the assignments made by students are in accordance with the results and demands of competence" (Melvia, junior high school teacher)

"I just give instructions to students, because many of the students already understand the form of the summary they will make, and it's very easy" (Nia, high school teacher)

Based on the interview results, it shows that there are differences in the way of giving examples to students. Modeling will increase students' self-efficacy if it is in the form of concrete examples, so students can measure and imagine the results of the tasks to be achieved later (Webb \& LoFaro, 2020).

The lowest self-efficacy indicators for middle and high school students are physiological and affective states. This indicator relates to passion, mood, anxiety, and stress experienced by students (Nurfauziah et al., 2018). Psychological and emotional states affect the level of stress and fear of a student in doing assignments. Students' fear of a task will weaken their performance and affect their self-efficacy (Burić \& Moè, 2020; Webb \& LoFaro, 2020). Students' self-efficacy will have a positive value if their thoughts are in line with their mood, and they will have negative associations with negative emotions (Burić \& Moè, 2020). Students at the junior high school level as early teens have a higher emotional level than high school students who have started to be emotionally stable, and this has an effect on the conversation in the interaction of the discussions carried out. In online learning, teachers who teach middle-level students, namely young teenagers, must be confident, knowledgeable, and maintain continuity of interaction with their students (Haverback, 2020).

Verbal persuasion indicators in junior high and high school students have a difference of $6.5 \%$. Verbal persuasion has more effect on high school students' self-efficacy than junior high school students. Verbal persuasion is the response or response of others to what we have done (Nurfauziah et al., 2018). Based on observations during discussion activities, it is seen that high school teachers often give praise, motivating sentences, positive feedback, and support to each of their students who are not active during discussions to invite students to be more active. Verbal persuasion during teaching can be in the form of positive, meaningful verbal, and written feedback that can be given by the teacher as encouragement for students (Webb \& LoFaro, 2020).

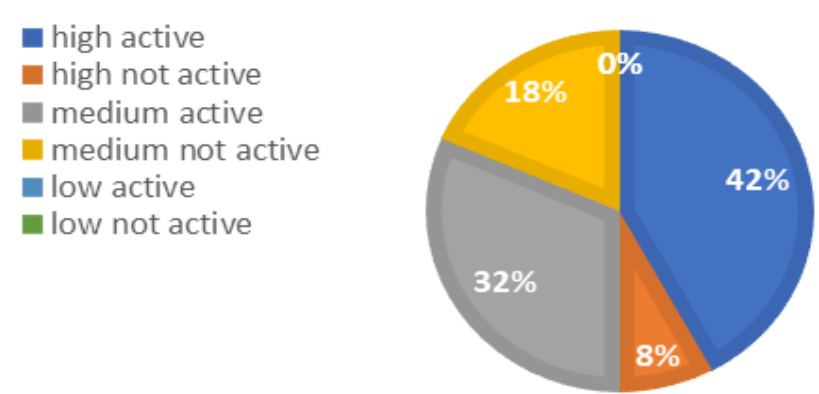

Figure 1. Self-Efficacy Diagram and Student Activity Level

Based on Figure 1, the results of the analysis of the level of student activity in group dynamics and the results of filling out self-efficacy questionnaires by students are obtained. $42 \%$ of students are included in the category of active discussion and have high selfefficacy. Students who have high self-efficacy have the confidence that they are able to complete all sorts of tasks given by teachers, dare to face risks by playing an active role in doing tasks, do not give up easily when facing obstacles, optimistic, and feel greater confidence in success than other students. Avsec \& SzewczykZakrzewska, 2018; Y. shan Chang et al., 2019; Huang et al., 2020). While $8 \%$ of students in discussion activities did not show activity, based on filling in, self-efficacy got high scores. Students who are active in discussions but have moderate self-efficacy scores are $32 \%$. Meanwhile, students who are not active in discussions have moderate self-efficacy. In this study, the average results for all aspects of self-efficacy were moderate, so there were none for the low category.

Several things cause differences in results, where inactive students have high self-efficacy due to their inconsistency in filling out self-efficacy questionnaires. Self-efficacy filling basically cannot be assessed with only one assessment because student self-efficacy is 
constantly changing due to various external or internal factors (Avsec \& Szewczyk-Zakrzewska, 2018; Vally et al., 2019). Students' self-efficacy conditions can only consistently last for approximately 1-5 days after learning takes place (Starkey et al., 2019).

\section{Conclusion}

There are differences in the discussion process in junior high school groups with asynchronous and synchronic high school groups, thus impacting the dynamics of interaction within the group on aspects of group role sharing, leadership, contributions when expressing ideas or ideas, contributions in doing tasks, and interdependence in the group. The percentage of self-efficacy of junior high and high school students is in the medium criteria. The mastery experience indicator comes from personal experience, and the highest score presentation is found in junior high school students compared to high school students. The vacarious experience indicator is modeling that can be given by the teacher or obtained from the experience of others, with the highest presentation obtained by high school students compared to junior high school students. Physiological and affective state indicators related to mood, arousal, fear, and stress were higher in high school students than junior high school students. Verbal indicators of student persuasion are responses or feedback from others about what students have done. The verbal persuasion of high school students is higher than that of middle school students. Based on the relationship between activity and group dynamics. There were active students with high self-efficacy, active students with moderate self-efficacy, active students with moderate self-efficacy, inactive students with moderate self-efficacy, and there were two categories not seen in the study, namely active students with moderate self-efficacy, low efficacy, and inactive students with low self-efficacy.

\section{References}

Asmuni, A. (2020). Problematika Pembelajaran Daring di Masa Pandemi Covid-19 dan Solusi Pemecahannya. Jurnal Paedagogy, 7(4), 281. doi: https://doi.org/10.33394/ip.v7i4.2941 [Indonesian]

Asnur, M. N. A., Adhima, F., Ayuwijayanti, M., \& Marsuki, R. R. (2019). Karaketristik Pembelajaran Kolaboratif Bahasa Asing dalam Google Classroom. Prosiding Seminar Nasional Literasi Bahasa Dan Sastra Ke-4 Pembelajaran Bahasa Asing Di Era Digital, 1-11. Retrieved from: http://sipeg.unj.ac.id/repository/...Seminar_Nas ional.pdf [Indonesian]
Asriadi. (2021). Jurnal Ilmiah Ilmu Kependidikan Manajemen Pembelajaran Daring Berbasis Kolaborasi dalam Meningkatkan Efektifitas Belajar. JIKAP PGSD :. 274-280. doi: doi: https://doi.org/10.26858/jkp.v5i2.20316 [Indonesian]

Avsec, S., \& Szewczyk-Zakrzewska, A. (2018). Engineering students' self-efficacy and goal orientations in relation to their engineering design ability. Global Journal of Engineering Education, 20(2), 85-90.

Burić, I., \& Moè, A. (2020). What makes teachers enthusiastic: The interplay of positive affect, selfefficacy, and job satisfaction. Teaching and Teacher Education, 89. doi: https://doi.org/10.1016/j.tate.2019.103008

Chang, S. H., Wang, C. L., \& Lee, J. C. (2016). Do award-winning experiences benefit students' creative self-efficacy and creativity? The moderated mediation effects of perceived school support for creativity. Learning and Individual Differences, 51, 291-298. doi: https:// doi.org/10.1016/j.lindif.2016.09.011

Chang, Y., shan, Chen, M. Y. C., Chuang, M. J., \& Chou, C. hui. (2019). Improving creative self-efficacy and performance through computer-aided design application. Thinking Skills and Creativity, 31(November 2018), 103-111. doi: https://doi.org/10.1016/j.tsc.2018.11.007

Corbett, F., \& Spinello, E. (2020). Connectivism and leadership: harnessing a learning theory for the digital age to rede fine leadership in the twentyfirst century. Heliyon, 6(April 2019), e03250. doi: https://doi.org/10.1016/j.heliyon.2020.e03250

Dong, C., Cao, S., \& Li, H. (2020). Children and Youth Services Review Young children's online learning during COVID-19 pandemic: Chinese parents' beliefs and attitudes. Children and Youth Services Review, 118(June), $105440 . \quad$ doi: https://doi.org/10.1016/j.childyouth.2020.105440

Fahmi, M. (2020). Komunikasi Synchronous Dan Asynchronous Dalam E-Learning Pada Masa Pandemic COVID-19. Jurnal Nomosleca, 6 (April). doi:

https://doi.org/10.26905/nomosleca.v6i2.4947. [Indonesian]

Haverback, H. R. (2020). Middle Level Teachers Quarantine, Teach, and Increase Self-Efficacy Beliefs: Using Theory to Build Practice during COVID-19. Middle Grades Review, 6(2), 6.

Heirida. (2017). Pengembangan Instrumen Untuk Mengukur Self Efficacy Siswa Dalam Pembelajaran Kimia. EDUSAINS, 9(1). doi: https://doi.org/10.15408/es.v9i1.40009 [Indonesian] 
Huang, N. tang, Chang, Y. shan, \& Chou, C. hui. (2020). Effects of creative thinking, psychomotor skills, and creative self-efficacy on engineering design creativity. Thinking Skills and Creativity, 37(March), 1-10.

https://doi.org/10.1016/i.tsc.2020.100695

Martin, F., Ritzhaupt, A., Kumar, S., \& Budhrani, K. (2019). Award-winning faculty online teaching practices: Course design, assessment and evaluation, and facilitation. The Internet and Higher Education, 42(March), 34-43. doi: https://doi.org/10.1016/j.iheduc.2019.04.001

Narayana, I. W. G. (2016). Analisis terhadap hasil penggunaan metode pembelajaran synchronous dan asynchronous. Semnasteknomedia Online, 4(1), 139-144. Retrieved from: https://ojs.amikom.ac.id/index.php/semnastekn omedia/article/view/1255 [Indonesian]

Nurfauziah, P., Faudziah, L., Nuryatin, S., \& Mustaqimah, I. A. (2018). Analisis Self Efficacy Matematik Siswa Kelas VIII SMP 7 Cimahi Dilihat dari Gender. Jurnal Matematika Dan Pendidikan Matematika, 3(1), 61-70. Retrieved from: http://www.journal.unipdu.ac.id/index.php/jm $\mathrm{pm} /$ article/view/1046 [Indonesian]

Oktariani, O. (2018). Peranan Self Efficacy Dalam Meningkatkan Prestasi Belajar Siswa. Jurnal Psikologi Kognisi, 41-50. Retrieved from: http://ejournal.potensi-...article/view/492 [Indonesian]

Puente-Díaz, R., \& Cavazos-Arroyo, J. (2017). The influence of creative mindsets on achievement goals, enjoyment, creative self-efficacy and performance among business students. Thinking Skills and Creativity, 24, 1-11. doi: https://doi.org/10.1016/j.tsc.2017.02.007

Rahmat, A. A., \& Rohyana, A. (2020). Pengembangan Prototipe Alat Bantu Latihan Reaksi Yang Mengunakan Sinyal Lampu Dan Bunyi Terhadap Kecepatan Lemparan Atas Softball. JUARA : Jurnal Olahraga, 5(2), 240-251. doi: https://doi.org/10.33222/juara.v5i2.855

[Indonesian]

Royston, R., \& Reiter-Palmon, R. (2019). Creative selfefficacy as mediator between creative mindsets and creative problem-solving. Journal of Creative Behavior, 53(4), 472-481. doi: https://doi.org/10.1002/jocb.226

Samsudin, M. A., Jamali, S. M., Zain, A. N. M., \& Ebrahim, N. A. (2020). The effect of STEM project based learning on self-efficacy among high-school physics students. Journal of Turkish Science Education, 17(1), 94-108. doi: https://doi.org/10.36681/tused.2020.15

Starkey, E. M., Hunter, S. T., \& Miller, S. R. (2019). Are creativity and self-efficacy at odds? an exploration in variations of product dissection in engineering education. Journal of Mechanical Design, Transactions of the ASME, 141(1), 1-11. doi: https://doi.org/10.1115/1.4041173

Sunaryo. (2017). Pengukuran Self-Efficacy Siswa Dalam Pembelajaran Matematika Di Mts N 2 Ciamis. Teorema: Teori dan Riset Matematika. 1(2), 39-44. doi: http://dx.doi.org/10.25157/teorema.v1i2.548 [Indonesian]

Syarifudin, A. (2020). Impelementasi Pembelajaran Daring Untuk Meningkatkan Mutu Pendidikan Sebagai Dampak Diterapkannya Social Distancing. Jurnal Pendidikan Bahasa Dan Sastra Indonesia Metalingua, 5, 31-34. doi: https://doi.org/10.21107/metalingua.v5i1.7072. [Indonesian]

Tantri, N. R. (2018). Kehadiran Sosial Dalam Pembelajaran Daring Berdasarkan Sudut Pandang Pembelajar Pendidikan Terbuka Dan Jarak Jauh. Jurnal Pendidikan Terbuka Dan Jarak Jauh, 19(1), 1930.

https://doi.org/10.33830/ptjj.v19i1.310.2018 [Indonesian]

Vally, Z., Salloum, L., AlQedra, D., El Shazly, S., Albloshi, M., Alsheraifi, S., \& Alkaabi, A. (2019). Examining the effects of creativity training on creative production, creative self-efficacy, and neuro-executive functioning. Thinking Skills and Creativity, 31(November 2018), 70-78. doi: https://doi.org/10.1016/j.tsc.2018.11.003

Wangwongwiroj, T., \& Yasri, P. (2021). A correlational study of self-efficacy and mindset: Building growth mindset through mastery experience and effort-based verbal persuasion. Psychology and Education, 58(2), 5260-5268. doi: https://doi.org/10.17762/pae.v58i2.2930

Wardani, A. D., Gunawan, I., Kusumaningrum, D. E., Benty, D. D. N., Sumarsono, R. B., Nurabadi, A., \& Handayani, L. (2020). Student Learning Motivation: A Conceptual Paper BT - Proceedings of the 2nd Early Childhood and Primary Childhood Education (ECPE 2020). 275-278. doi: https://doi.org/https://doi.org/10.2991/assehr. k.201112.049.

Webb, D. L., \& LoFaro, K. P. (2020). Sources of engineering teaching self-efficacy in a STEAM methods course for elementary preservice teachers. School Science and Mathematics, 120(4), 209- 219. doi: https://doi.org/10.1111/ssm.12403 Zhang, H., Sun, C., Liu, X., Gong, S., Yu, Q., \& Zhou, Z. (2020). Boys benefit more from teacher support: Effects of perceived teacher support on primary students' creative thinking. Thinking Skills and Creativity,37(April). doi: https://doi.org/10.1016/i.tsc.2020.100680 